\title{
Banglascapes in Southern Europe: Im-mobilities, emplacements, temporalities
}

\author{
Andrea Priori ${ }^{1}$, José Mapril², and Francesco Della Puppa ${ }^{3}$
}

This special issue stems from a panel we organised at the European Conference on South Asian Studies in 2018, under the title 'Banglascapes in Southern Europe: comparative perspectives'. Not all the panel participants from that conference feature in this special issue, and not all the authors included here were present at the conference. Nevertheless, the panel represents a first important moment in which we began to collect case-studies and insights on a relatively new aspect of the so-called Bengali, or Bangladeshi, 'diaspora'.

In recent years, the dynamics of Bangladeshi migrations in Europe have changed significantly. If, up until the 1990s, the Bangladeshi presence on the continent was metonymically epitomised by the British-Bangladeshi 'community', the last decade of the twentieth century has seen the emergence of the influence of Southern European countries, such as Italy (which has the largest Bangladeshi community in Europe after that in Britain), Spain, Portugal, and Greece, due to the changing role of these countries in relation to global migrations. Frequently perceived as emigration countries, since the 1980s, several Southern European countries have also become immigration destinations (Zeytlin 2006).

In addition, in response to significant changes in the immigration and asylum policies of Middle and Northern European countries (Knights and King 1998), Bangladeshis have settled in Madrid, Barcelona, Rome, Venice, Lisbon, Porto, and Athens, among many other cities, establishing complex relations with the different immigration regimes, labour market structures, and models of incorporation at national and city levels.

Simultaneously, in recent years, changing economic policies (specifically, the application of austerity measures in the larger context of neoliberal readjustment programmes) have elicited onward migration (Della Puppa et al. 2021), mainly towards the UK, and reconfigurations in im-mobility trajectories which have added a further layer of complexity to the internally diverse scenario of the Bangladeshi diaspora in Europe (Della Puppa and Sredanovic 2017; Priori 2017, Mapril 2021). In this context, Southern Europe represents at the same time a final destination for making a living, an increasingly important hub linking Bangladeshis in Europe and worldwide and, sometimes, a stage in onward migration routes and trajectories (Della Puppa 2014; 2018; Della Puppa and King 2019; Mapril 2012; 2014a; Priori 2010; 2012a; 2019; Zeytlin 2006).

\footnotetext{
${ }^{1}$ Andrea Priori, Fulda University of Applied Sciences, Germany. E-mail: andrea.priori@sk.hs-fulda.de.

${ }^{2}$ José Mapril, Universidade Nova de Lisboa, Lisbon. E-mail: jmapril@gmail.com.

${ }^{3}$ Francesco Della Puppa, Ca' Foscari University in Venice, Italy. E-mail: francesco.dellapuppa@unive.it.
} 


\section{Banglascapes in Southern Europe: Im-mobilities, emplacements, temporalities}

With respect to the multiplicity of configurations that Southern Europe may assume for the Bangladeshi diaspora, we wish to underscore here that it cannot be considered merely a 'waiting room' for Northern European contexts - by which we mean primarily the United Kingdom. In fact, we believe that, within the boundaries of the phenomenon of intraEuropean onward migration towards northern countries and the UK that characterises the Bangladeshi Diaspora - especially in the years between the 2008 economic crisis and the advent of Brexit (Lulle et al. 2018; 2019) -, the envisaging of Southern Europe as a 'transit area' for previously planned migrations to the British context belies an excessive mechanicism and determinism. We argue that the phenomenon does not represent a consciously predetermined strategy by Bangladeshi workers and their families who had formerly migrated to Southern Europe, but it is the result of a combination of both objective and subjective, and both structural and individual, factors. On the one hand, one should take into consideration the transformation of the global - and, above all, European - economic landscapes, resulting from the aforementioned economic crisis of 2008, with its negative repercussions on the labour market, especially in Southern European countries, and the resulting limitations of social mobility for younger generations. On the other hand, we must also consider changes which have taken place within individual and family biographies of Bangladeshi probashir (migrants) in the years from their arrival in Southern Europe to more recent ones: they are no longer middle-class Bangladeshi men, celibate and childless, who have migrated for personal fulfilment and/or for the sustenance and growth of their family back home through remittances, but they are instead husbands and wives who have been reunited with their families, or created a family in Europe, and who feel responsible for them, with a corresponding habitus and aspirations for social realisation (and mobility), that are typical for those of their social class, and who have often become European citizens. Therefore, any reactivation of migration mobility, for example, an onward migration towards the UK, is not the outcome of a pre-ordered plan, but rather a response to class aspirations or individual and family needs in a profoundly transformed economic and social scenario, one which has gradually taken shape over the years. Within this framework, the acquisition of European citizenship assumes the crucial role (Della Puppa and Sredanovic 2017; Mapril 2021) due to the resulting increased motility (Kaufmann et al. 2004).

Despite the crucial role and importance of Southern Europe for Bangladeshis, and a growing body of literature on Bangladeshi migrants in countries such as Portugal (Mapril 2010; 2012; 2014a; 2014b; 2017; 2019), Spain (Zeitlyn, 2006; Martín-Saiz 2017), Italy (Della Puppa 2014; King and Della Puppa 2020; Knights 1996; Knights and King 1998; Mantovan 2007; Morad and Della Puppa 2019; Priori 2010; 2011; 2012a; 2012b; 2014; 2017; Quattrocchi et al. 2003), or Greece (Fouskas 2012; Kassimeris and Samouris 2012), there is still no comparative approach looking at the impact of the different national and city contexts on our interlocutors' experiences, nor at the connections (economic, political, religious, ritual, among others) which they have created between different European countries in the past decades.

This special issue brings together scholars who focus on different features of Bangladeshi migrations in countries such as Portugal, Spain, Greece, and Italy, with the aim of accounting for the intermeshing of Southern European destinations and routes into the worldwide dynamics of im-mobilities. We want to provide insights on the dialectic between emplacement processes and connectivity, and the multiple and complex ways of making 'Banglascapes', and being Bengali and Bangladeshi. 
By doing so, this special issue attempts to make a contribution to the literature on Bengali/Bangladeshi diasporas; a field which, in recent years, has seen an important turning point with the publication of The Bengal Diaspora, the book authored by Alexander, Chatterji, and Jalais in 2016. If The Bengal Diaspora urged migration scholars to take into account the existence of different articulations of the diaspora, and recognise the importance of migration movements towards the global South, then the contributions to this special issue provide further examples of the complex nature of Bangladeshi migrations by focusing on the "South of the North", highlighting both its specificity compared to the foundational model represented by the British context, and its internal diversities (Eade 1989; Eade et al. 1996; 2002, Gadner 1995; 2002; Zeitlyn 2016, inter alia). To put it another way, by addressing the Bangladeshi migration in Southern Europe, this special issue brings to the surface the importance of new geographies of the Bengali/Bangladeshi diasporas.

One might well ask: Why focus exclusively on Southern Europe? The answer is, and this is our contention, that Southern European contexts present historical-structural specificities in relation to other contexts in Europe, and these specificities affect Bangladeshi migrations and subjectivities in particular ways. For instance, whereas in the UK or other Northern or MiddleEuropean countries informality is an exception, in the four countries to which this special issue is devoted it seems to be quite the norm. Migration scholars have successfully covered this informality using the definition of 'Mediterranean model of migration' (King 1993; King and Black 1997; King and De Bono 2013; King et al. 1999; Pugliese 2002; 2011), highlighting certain characteristics, such as the absence of specific migration governance policies and the frequent use of amnesties; the social marginality of migrants and the large presence of "irregular" residents; or a concentration of the migrant workforce in heavy, demeaning, precarious and, often, informal occupations, as salient features of the migrant population in this geographic area. Portugal has been included in this area not only because of its historical connections with the Mediterranean world, but primarily because its models of incorporation have strong family resemblances with those of Italy, Greece, and Spain. The multidimensional precarity emphasised by the Mediterranean model, whose effect has only been exacerbated, following the economic crisis at the end of the 2000s, is embodied in the lives of our interlocutors in different forms and elicits an existential uncertainty which opens up liminal spaces where both migratory paths are renegotiated and struggles to make a living locally take place (Mapril 2019; Priori 2017; 2019). Although it is important to acknowledge that the location and impact of informality and precarity vary according to national and city contexts - in relation to labour market structures, economic sectors, and development policies - and individual social capital, such structural vulnerabilities seem to be quite widespread in Southern Europe.

Besides this structural commonality, each of the countries has a specific migration history, one connected to colonial and post-colonial dynamics and mobilities. These have produced dominant discourses about immigration and asylum policies, which, in turn, have an impact on immigration regimes and, therefore, on our interlocutors' experiences and forms of participation. These immigration regimes become more complex when one bears in mind that they are frequently articulated in line with European Union guidelines and 'integration' plans (for instance, the Intercultural Cities Programme by the European Commission).

Nonetheless, the contradictory nature of the structures of opportunities available in Southern Europe locates this area within the vast and hierarchically-organised space of the Bangladeshi 
diaspora (Priori 2017; cf. Gupta and Ferguson 1992; Fog Olwig and Harstrup. 1997) as a desirable 'mooring'. At least in terms of economic opportunities, it is more desirable than Bangladesh or the oil-producing countries in Northern Africa and Eastern Asia, but still less attractive than the UK or Germany. Power-geometries (Massey 1993) superimposed over the geographic space inspire some migrants to move first from Bangladesh to Libya, and then from Libya to Italy (Del Franco in this SI), or from Libya to Greece (Minamide in this SI), just like they inspire others to undertake new mobilities towards London after obtaining citizenship in Italy or Portugal (Della Puppa in this SI, or Mapril 2021), or to project further movements from Greece to Germany (Fratsea and Papadopulos in this SI).

While the space of the Bangladeshi diaspora is crosscut by im-mobility trajectories which do not point exclusively to 'the north', it is also true that in some cases, for example when people have access to adequate mobility capital, these trajectories are indeed affected by a certain magnetism to the north in which London represents the main pole of attraction. Moreover, the old colonial capital does not only exert an influence in that it represents the ultimate desired mooring of some fragmented migratory paths, but it also operates as a centre, radiating out cultural tendencies and imaginaries of the Bangladeshi community. In this way, immaterial artefacts such as religious orientations (Priori; Salguero and Hejazi in this SI) or patterns of self-organisation (Mantovan in this SI), which have proved to be productive in the context of the British-Bangladeshi community, are appropriated and translated into Southern European idioms and emplaced in local processes.

If this special issue devotes particular attention to mobility and connectivity, the desire to lead local lives and establish Bangladeshi spaces in Southern European sites can be seen as a complementary characteristic, one which does not necessarily stand in opposition to movement. The contributors highlight the importance of place-making processes and connectivity with local actors in diverse fields, such as the production of a public Islam (Priori; Salguero and Hejazi in this SI), the appropriation of urban space (Piazzoni; Salguero and Hejazi in this SI), and the emergence of local associations led by migrants (Mantovan in this SI), demonstrating the reciprocal entanglements of these local, sedentary processes with transnational fluxes and mobilities (Mapril in this special issue).

But what then are the consequences of all this to the ways of being and the ways of belonging (Levitt and Glick Schiller 2004) of our interlocutors? Of being Bangladeshi and Bengali in Southern Europe?

The fact that we are focusing exclusively on Bangladeshis in Southern Europe does not mean that we are reifying Bangladeshiness or leaving it unquestioned from an empirical point of view. On the contrary, we intend to show how being Bangladeshi and Bengali are highly contested and debated terms, which vary according to migration histories, class, gender, and generation, but also with immigration regimes and dominant discursive formations. The internal diversity of the Bangladeshi diaspora is a theme which connects all the contributions in this SI. For instance, due to the configuration of Bangladeshi migration flows to Southern Europe, it is possible to find several chain migrations that originate in different parts of Bangladesh. This has led to enormous diversity along regional lines, corresponding to many different associations and voluntary groups (Mantovan; Priori in this SI). On one level, this has reinforced regional identities, for example being a Chittagongian in Lisbon, but on 
another, it has led to efforts to create initiatives and events that mobilise ideas and imaginaries about being Bangladeshi (Mapril in this special issue). This concern with Bangladeshiness overlaps with other transnational domains such as homeland politics and the omnipresence of different political allegiances and their ideas about what it is to be a Bangladeshi or Bengali.

Moreover, Bangladeshiness does not stand alone, untouched by other forms of national identifications. Those who settle in a new country start to consider new forms of belonging and can identify as hyphenated-Bangladeshis (Eade, 2007), or elaborate creative identifications which combine national and religious belongings, a trend which is particularly evident among the so-called 'second generations' (Priori in this SI). Unsurprisingly, the concerns of parents are not necessarily followed by their children, and intergenerational differences emerge quite strikingly, not only in relation to Bangladeshiness and Bengaliness, but also with respect to Islam, leisure activities, and marriage strategies among others, highlighting processes which are paralleled in other diasporic contexts, and in shodesh (motherland) (Gavron 1996; Rozario 2011).

In addition, living in a country for a few years does not only elicit self-identifications as ItalianBangladeshi, or Spanish-Bangladeshi, but also forms of hetero-identification by migrants living in other parts of Europe. People can be labelled as Italian-Bangladeshis even if they think of themselves simply as Bangladeshis, and these complex identifications can add to other complexities creating, for example, juxtapositions between Dhakaite-ItalianBangladeshis and Sylheti-British-Bangladeshis (Della Puppa in this special issue).

Therefore, being Bangladeshi in Lisbon is not the same thing as in Rome or in London, partly because of contextual elements. For instance, in Lisbon, the intercultural model of citizenship has elicited the emergence of certain cultural expressions by migrant populations in the public sphere. It is in this context that several Bangladeshi entrepreneurs organised to build a replica of the Shaheed Minar ${ }^{4}$ in a central square in Lisbon (Mapril 2017). Whereas in the UK a replica of the Shaheed Minar in Altab Ali Park was built in the context of anti-racism movements (Alexander 2013), in Lisbon it was part of a larger effort to claim a public space in the context of the intercultural immigration regime. The efforts were organised by a group of local Portuguese-Bangladeshis who seek recognition not only as Bangladeshis but also as important economic actors in downtown Lisbon (Mapril 2017).

In Rome, the issue of the Shaheed Minar is also connected with politics of recognition, but it took different forms, due to the presence of a larger, and internally divided, Bangladeshi community, and to an ethnicised model of appropriation of the urban space. Here, the Shaheed Minar became a way to consecrate Bangladeshi neighbourhoods as 'Banglatowns' and to express political juxtapositions (Priori 2012a). Two opposing political groups erected two different replicas, one in Esquilino and one in Torpignattara, but both replicas were removed due to lack of authorisation from the local councils. A few years later, a third replica was built in an upper-class neighbourhood in Rome where Bangladeshi presence is almost

\footnotetext{
4 The Shaheed Minar is a national monument located in Dhaka, built to commemorate the martyrs of the mother tongue preservation movement killed by the Pakistani army on the $21^{\text {st }}$ of February 1952. Erected by the students of Dhaka in the night of the massacre and soon destroyed by the Pakistani army, after the independence of Bangladesh, in 1971, the monument was rebuilt. Today the Shaheed Minar is the center of Dhaka's cultural activities. The victims of the extermination are remembered on $21^{\text {st }}$ of February and recently the same date was chosen by Unesco as the International day of the mother tongue. Today, the monument is one of the main symbols of the Bangladeshi national identity, even if, around it, different interpretations and political visions of historical events and the war that Bangladeshi historiography calls 'Liberation war' clash each other (Alexander, 2013; Mapril, 2014b; 2017).
} 


\section{Banglascapes in Southern Europe: Im-mobilities, emplacements, temporalities}

irrelevant, as a result of diplomatic relations between the Italian Government and the Embassy of Bangladesh. Unlike the other two, this third replica is still there.

Similar dynamics, characterised by fractures and conflicts between associations - which take place along regional lines or personal differences - and political groups' struggling for community recognition, often supported by Italian institutional actors, have taken shape within other Bangladeshi communities in Italy (Mantovan 2007; Morad and Della Puppa 2019). In the case of the Bangladeshi community residing in the Province of Padua, the Shaheed Minar ${ }^{5}$ is the result of a particular closeness and synergy between the traditionally politically left local government of the municipality of Cadoneghe - in which the main migrant community is by far the Bangladeshi one -, and the 'Bangladeshi Association' which has managed to hegemonically impose itself with respect to intra-community associations. In this case, from the perspective of the destination society, the monument replica symbolises an acceptance of the resident migrants, thus inadvertently approximating the situation in Lisbon. However, from the perspective of the Bangladeshi community in Padua, it constitutes both a recognition of their presence and, echoing similarities in the context of Rome, the outcome of a political and associative intra-community conflict.

At the same time, in several Southern European contexts, Bangladeshis have created both religious and secular institutional apparatus that forms a dialogue with the religious and secular infrastructure, and the dominant discourses and institutions concerning religion, including the prominent role of the Catholic and Orthodox Churches. For instance, although it is possible to find Islamic prayer rooms in Athens, several conservative segments have blocked the construction of a central Mosque. This has elicited a specific Islamic institutional framework which is quite distinct from that in Portugal. In the latter, the Catholic Church joined with other religious groups, perceived as less recognised religious minorities, in order to claim a place for them. This has created opportunities for the emergence of new institutional scenarios, including those for Bangladeshis.

One might argue that some of these phenomena have already taken place within the Bangladeshi diaspora in the UK, and to a certain extent this view has merit. But at the same time, it is the relation of these idioms to the historical-structural dynamics in Southern Europe that gives meaning to what our interlocutors are saying and doing. This, in turn, makes clear that being Bangladeshi and Bengali in Italy, Portugal, Spain or Greece is not exactly the same thing as in the UK.

Our choice in approaching this field through fine-grained ethnographic analyses elicited a variety of themes which offer straightforward examples of the internal diversity of the Southern European diaspora.

Mapril shows how local relationships are re-embedded in transnational networks by analysing the creation of a transnational federation of Bangladeshi associations. This allows him to reflect on the concept of diaspora itself, as well as those of diasporic public space, and longdistance nationalism. Del Franco analyses the construction of narratives of migration in the context of the complicated and extenuating processes of evaluating asylum applications of

${ }^{5}$ To the best of the authors' knowledge this is the second permanent Shaheed Minar constructed in Italy (after the one in Bari) and the third in Europe (after that in London). 
Bangladeshi migrants who have fled from Libya to Italy following the inception of the second civil war. Della Puppa deals with a more selective and desired vector of onward mobility which connects Italy to the UK, and focuses on the representations of the class and district-related dynamics which divide the Sylheti 'community' of London from the 'Italian' newcomers.

Fratsea and Papadopulos offer another picture of the fragmented scenario of Bangladeshi immobilities by combining quantitative and ethnographic data in order to describe the impact of precarity on the trajectories of migrants living, or transiting, in Greece. Minamide presents a multi-sited ethnography linking Athens and a cluster of Bangladeshi villages, in which she analyses the emotional strategies and the structure of opportunities available for different generations of migrants, paying specific attention to the consequences of migrations for those who remained in the motherland.

Piazzoni explores the nexus between mobile people and local urbanism by taking into account the role of Bangladeshi street-sellers in place-making processes which, quite counterintuitively, do not occur in the ethnicised space of the Bangladeshi enclaves of Rome, but rather in the iconic touristic landscape of its central area. In a contrasting context, $\underline{\text { Salguero }}$ and Hejazi articulate the theme of the right to the city, where ethnicisation of the urban space is leveraged in the process of emplacement of a Bangladeshi Islam in Madrid, and in the creation of relationships with local actors.

Priori approaches Bangladeshi Islam from a generational standpoint by dealing with young Muslim activists in Rome, whose religious and existential critique of the adults resonates not only with rhetoric circulating within transnational Islamic networks, but also with their concrete life conditions at a local level. Mantovan explores another kind of activism by tracing a reasoned genealogy of an archipelago of secular migrant associations in North-Eastern Italy, and by contextualising this nebula of organisations within political scenarios, both in the motherland and Italy, highlighting connections at the local and transnational level.

The choice to build this special issue around specific case-studies entails not only a variety of themes, but also a multiplicity of interlocutors: young people (Minamide; Priori) and adults (Della Puppa; Mantovan); newcomers (Piazzoni; Del Franco) and well-established migrants (Mapril; Della Puppa; Mantovan); Islamic activists (Salguero and Hejazi; Priori) and secularist people (Della Puppa; Mapril); underpaid workers (Minamide, Fratsea and Papadopulos), street sellers (Piazzoni), and aspiring professionals (Priori); and both migrants with poor educational backgrounds (Del Franco; Fratsea and Papadopulos) and people with access to university education (Della Puppa; Priori).

These diverse interlocutors incarnate different aspects of the Bangladeshi diaspora in Southern Europe, and their stories show how the same idea or the same social asset can be interpreted and employed in various, and often opposite, ways by different people, depending on their positionalities. If, for example, Bangladesh works as a Procrustean bed on which to measure the successfulness of one's trajectory for the generation of the 'first migrants' (Minamide in this SI; see also Gardner 1995; Priori 2011; 2012a; Della Puppa 2014), those who migrated to Europe as children or were born there see their parents' reverence of the shodesh as an anachronism hindering their personal development (Priori in this SI; see also Gardner and Shukur 1994). Similarly, the presence of an established Bangladeshi community can be interpreted by migrants as an asset (Mapril; Salguero and Hejazi; Mantovan in this SI; 


\section{Banglascapes in Southern Europe: Im-mobilities, emplacements, temporalities}

see also Eade 1989; Eade et al. 1996; Zeitlyn 2006) or a burden (Piazzoni in this SI), based on their position within the power structures of the community itself (Priori 2010; 2012a; 2012b).

From this perspective, it is quite straightforward to conclude that the various Bangladeshi communities scattered around Europe are internally diverse and that, despite its peculiarities with regards to models of incorporation, the Southern European diaspora needs further intersectional categorisation in order to be understood, just like any other general label. In some cases, people pertaining to different 'categories' meet in the same setting. This is the case in the contribution of Minamide, in which people who had arrived in Greece at different times demonstrate different approaches to the migration experience. Another example is provided by the case-study presented by Priori, where an opposition relationship between two generations of Italian-Bangladeshis is depicted. In the article authored by Della Puppa, social and district-based differences are performed in London, a scenario exceeding the areal limitations of this special issue, where the representation of a conflict between Italian probashir and Londoni epitomises symbolically dense oppositional lines, such as rural-urban, secularreligious, educated-uneducated. The case-study presented by Della Puppa illuminates another important difference between the European 'south' and the British context. In fact, while emigration towards the UK was primarily by people from a specific social group, the taluk dars (small landholders), from the Sylheti district, migrations towards Southern Europe originate from a greater variety of sources, both in terms of Bangladeshi districts and social origins, resulting in more diversified migratory chains. Countries such as Italy, Spain, Portugal, and Greece welcomed a mix of migrants with both rural and urban origins, from different districts and cities, and an internally diverse array of self-appointed borolok (people of high status), whose positions on the Bangladeshi social ladder range from small landholders with an endangered familial status, to urban middle-class migrants with relatively solid social and cultural capital (cf. Priori 2012a; Mapril 2014a). This greater heterogeneity is reflected in the dynamics of political self-organisation which produced more centrifugal outcomes compared to those of the UK (Mantovan; Priori; Salguero and Hejazi in this SI), also in respect to the different models of incorporation implemented by the institutions.

While positionality represents a possible route for navigating Southern European Banglascapes, at the same time it highlights some of the shortfalls of our analysis. Despite the growing number of minors with Bangladeshi origins in Southern Europe, children are largely absent from this special issue. The Hindu component of the diaspora is also lacking from our picture, and we run the risk of reducing religion to solely Islam, the religion of the majority. In this respect, we cannot help but draw attention to the poor scholarly interest overall in these themes in Southern Europe, at least so far. A third remarkable limit of this special issue is that a specific attention to women is almost completely missing, a characteristic mirrored in the relative scarcity of scientifically relevant contributions referencing Southern European countries (cf. Cristofori 2011; Priori, 2017; Della Puppa 2018). This is partially explained by the nature of the subjects included in this special issue. Many contributors deal with primary migration processes, in which hegemonic cultural constructions assign men the role of firstmigrant, with the role of opening the family 'migration chain' and achieving consequent family reunification with wives and children. In other contributions, for example those concerned with processes of self-organisation, men are often in the spotlight because of their grasp of power in secular and religious associations which aspire to represent the community or at least relevant parts of it, while another contribution deals with street sellers, a category of workers in which Bangladeshi women do not figure. As a matter of fact, in Southern Europe as in 
Bangladesh, many Bangladeshis tend to reproduce segregated models of sociality, with the women removed as much as possible from the labour market, and women's organisations carefully separated from those of men and from the politics of the community (Eade 1990).

Nevertheless, we are aware of the pitfalls of reproducing hegemonic representations by portraying the Southern European probashir in this way, and wish to draw the reader's attention to our view that, although first migrants are generally men, women's agency in Bangladeshi im-mobilities is still substantial, especially with regard to emplacement processes and onward migrations (Della Puppa 2018; Priori 2017; 2019), and that in Southern Europe there is a growing number of Bangladeshi women accessing the labour market or running entrepreneurial activities. Similarly, although the most visible organisations are led by men, women's associations have shown themselves to be reliable civil society actors in various Southern European cities. Furthermore, despite the salience of a pattern of family reunification, scholarly research cannot assume that Bangladeshi sociality is exclusively based on a model of heterosexual marriage. These themes pinpoint the scientific limits of our work, providing important vectors for further research, and making it clear that there are more ways to be a Southern European probashi in the thick of social life than merely those represented in our ethnographies.

\section{References}

Alexander, C. (2013). "Contested memories: the Shahid Minar and the struggle for diasporic space". Ethnic and Racial Studies, 36(4), 590-610.

Alexander, C., Chatterii, J. and A. Jalais. (2016). The Bengal Diaspora. Rethinking Muslim Migration. AbingdonNew York: Routledge.

Cristofori, S. (2011). "'Non esce pensiero se non c'è possibilità'. La Bangla Accademy, il tempo delle donne e il radicamento familiare probashi”, in F. Pompeo (Ed), Pigneto-Banglatown. Migrazioni e conflitti di cittadinanza in una periferia storica romana, Rome: Meti, pp. 93-117.

Della Puppa, F. (2014). Uomini in movimento. Il lavoro della maschilità tra Bangladesh e Italia. Torino: Rosenberg \& Sellier.

Della Puppa, F. (2018). "Ambivalences of the emotional logics of migration and family reunification: emotions, experiences and aspirations of Bangladeshi husbands and wives in Italy", Identities. Global Studies in Culture and Power, 25(3): 358-375.

Della Puppa, F., Montagna, N. \& Kofman, E. forthcoming (2021), 'Onward Migration and Intra-European Mobilities: A Critical and Theoretical Overview', International Migration.

Della Puppa, F. and King, R. (2018). "The New 'Twice Migrants': Motivations, Experiences and Disillusionments of Italian-Bangladeshis Relocating to London", Journal of Ethnic and Migration Studies, 45(11): 1936-1952.

Della Puppa, F. and Sredanovic, D. (2017). "Citizen to stay or citizen to go? Naturalisation, security, and mobility of migrants in Italy", Journal of Immigrant and Refugee Studies, 15(4): 366-383.

Eade, J. (1989). The politics of community. The Bangladesh Community in East London, Aldershot: Avebury.

Eade, J. (1990). "Nationalism and the quest for authenticity: The Bangladeshis in Tower Hamlets", Journal of Ethnic and Migration Studies, 16(4): 493-503.

Eade, J. (2007). "Economic Migrant or Hyphenated British? Writing about difference in London's East End”, in Gupta, S. and Omoniyi, T. The Cultures of Economic Migration: International Perspectives. London: Routledge, pp. 27-36.

Eade, J. Fremeaux, J. and Garbin, D. (2002). “The political construction of diasporic communities in the global city", in P. Gilbert (ed), Imagined Londons, Suny Press, Albany, pp. 969-988.

Eade, J., Vamplew, T. and Peach, C. (1996). “The Bangladeshis: The encapsulated community”. In C. Peach (ed), Ethnicity in the 1991 census, London: HMSO, pp. 150-160.

Fog Olwig, K. and Harstrup, K.. (1997) (eds.). Siting Culture. The Shifting Anthropological Object, London-New York: Routledge. 
10 Banglascapes in Southern Europe: Im-mobilities, emplacements, temporalities

Fouskas, T. (2012). "Low-Status Work and Decollectivization: The Case of Bangladeshis in Athens". Journal of Immigrant \& Refugee Studies, 10, 54-73.

Gardner, K. (1995). Global Migrants, Local Lives. Migration and Transformation in Rural Bangladesh. Oxford Oxford; University Press.

Gardner, K. and Shukur, A. (1994). "I'm Bengali, I'm Asian, and I'm living here' The changing identity of British Bengalis". In: R. Ballard (ed), Desh-Pardesh. The South Asian presence in Britain, Hurst \& Co., London: 142-164.

Gavron, K. (1996). Du mariage arrangé au mariage d'amour, Terrain, 27: 15-26.

Gupta, A., and J. Ferguson. (1992). "Beyond Culture: Space, Identity, and the Politics of Difference." Cultural Anthropology, 7 (1): 6-23.

Kassimeris, G. and Samouris, A. (2012). "Examining Islamic Associations of Pakistani and Bangladeshi Immigrants in Greece”. Religion, State \& Society, 40(2), 174-191.

Kaufmann V, Bergman MM and Joye D (2004) Motility: Mobility as capital. International Journal of Urban and Regional Research, 4: 745-756.

King, R. (ed.) (1993). The New Geography of European Migration, London: Belhaven Press.

King, R. and Black, R. (eds.) (1997). Southern Europe and the New Immigrations, Brighton: Sussex Academic Press.

King, R. and De Bono, D. (2013). "Irregular migration and the 'Southern European Model of Migration"'. Journal of Mediterranean Studies, 22(1): 1-31.

King, R. and Della Puppa, F. (2020). "Times of Work and Social Life: Bangladeshi Migrants in Northeast Italy and London". International Migration Review.

King, R., Lazaridis, G. and Tsardanidis, C. (eds) (1999). Eldorado or Fortress? Migration in Southern Europe, Basingstoke: Palgrave.

Knights, M., (1996). "Bangladeshi immigrants in Italy: from geopolitics to micropolitics." Transactions of the Institute of British Geographers, n. 21, pp. 105-123.

Knights, M., King, R., (1998). “The Geography of Bangladeshi Migration to Rome.” International Journal of Population Geography, n. 4, pp. 299-321.

Levitt, P. and Glick Schiller, N. (2004). "Conceptualising Simultaneity: A Transnational Social Field Perspective on Society.” International Migration Review, 38(3): 1002-1039.

Lulle, A., Moroşanu, L. and King, R. (2018). "And then came Brexit: Experiences and future plans of young EU migrants in the London region." Population, Space and Place, 24(1).

Lulle, A., King, R., Dvorakova, V. \& Szkudlarek, A. (2019). "Between disruptions and connections: "New" European Union migrants in the United Kingdom before and after the Brexit." Population, Space and Place, 25(1), e2200.

Mantovan, C. (2007). Immigrażone e cittadinanza. Auto-organizzazione e partecipazione dei migranti in Italia, Milan: Franco Angeli.

Mapril, J. (2010). "Banglapara: imigrações e (in)formalidades em Lisboa.” Etnográfica, 14(2): 243-264.

Mapril, J. (2011). "The patron and the madman: migration, success and the (in)visibility of failure among Bangladeshis in Portugal." Social Anthropology, 19(3), 288-296.

Mapril, J. (2012). Islão e Transnacionalismo: Uma Etnografia entre Portugal e o Bangladeche, Lisboa, Imprensa de Ciências Sociais,

Mapril, J. (2014a). "The dreams of middle class: consumption, life-course and migration between Bangladesh and Portugal." Modern Asian Studies, 48 (3): 693-719.

Mapril, J. (2014b). "A Shahid Minar in Lisbon: long distance nationalism, politics of memory and community among Luso-Bangladeshis.” South Asia Multidisciplinary Academic Journal, 9.

Mapril, J. (2017). "A past that hurts: memory, politics and transnationalism between Bangladesh and Portugal", in Monika Palmberger, Jelena Tošić (orgs.), Memories on the Move: Experiencing Mobility, Retbinking the Past, Londres, Palgrave Macmillan, pp. 247-270.

Mapril, J., (2019). "Waiting for the future in Lisbon: Borders, migrations and biographies in a banglascape", International Journal of Migration and Border Studies 5 (4): 324-338.

Mapril, J. (2021). "Placing the future: Onward migration, education and citizenship among PortugueseBangladeshi in London." International Migration.

Martín-Saiz, G. (2017). "Islam and the Tablighi Jama'at in Spain: Ghosts of the Past, Limits of Representation, and New Developments”. In Mapril, José, Ruy Blanes, Emmerson Giumbelli, and Erin

Migration Letters 
K. Wilson (eds.). Secularisms in a Postsecular Age? Religiosities and Subjectivities in Comparative Perspective. London and New York: Palgrave Macmillan.

Morad, M. and Della Puppa, F. (2019). "Bangladeshi Migrant Associations in Italy: Transnational Engagement, Community Formation and Regional Unity", Ethnic and Racial Studies, 42(10): 1788-1807.

Priori, A. (2010). "Vita segreta delle 'etnie': politica e stratificazione sociale a Banglatown", Zapruder. Rivista di storia della conflittualità sociale, 22: 38-54.

Priori, A. (2011). “«Per la casa chiedo a amici, parenti, per il lavoro chiedo a Diol»: condizione alloggiativa, inserimento lavorativo e riterritorializzazione nella Banglatown romana", in F. Pompeo (ed.), PignetoBanglatown. Migrazioni e conflitti di cittadinanza in una periferia storica romana, Meti Edizioni, Roma, pp. 57-90.

Priori, A. (2012a). Romer Probashira: Reti Sociali e Itinerari Transnazionali Bangladesi a Roma. Rome: Meti.

Priori, A. (2012b). "Murghi, patron e padroni. Specularione, esclusione sociale e differenza culturale fra $i$ migranti bangladesi a Roma", in F. Pompeo, a cura, Paesaggi dell'esclusione, Torino, UTET.

Priori, A. (2014). "La difesa dello spazio: le aggressioni ai bangladesi in un quartiere della periferia romana", Archivio di Studi Urbani e Regionali, 110, pp. 95-114.

Priori, A. (2017). "Bangladeshi multi-scalar im/mobilities: Between social aspirations and legal obstacles". New Diversities, 19 (3): 29-42.

Priori, A. (2019). "Soggetti al potere/soggetti di potere: im/mobilità multiscalari bangladesi fra coercizione e agency", in B. Riccio (ed.), Mobilità - incursioni etnografiche, Mondadori, Milano.

Pugliese, E. (2002). L'Italia tra migraz̧oni internazionali e migrazioni interne, Bologna: Il Mulino.

Pugliese, E. (2011). 'The Mediterranean model of immigration'. Academicus International Scientific Journal, 3: 96107.

Quattrocchi, P., Toffoletti, M. and Tommasin, E.V. (2003). Il fenomeno migratorio nel Comune di Monfalcone. Il caso della comunità bengalese. Gradisca d'Isonzo: AREAS.

Rozario, S. (2011). "Islamic piety against the family: From 'traditional' to 'pure' Islam”, Contemporary Islam, 5: 285-308.

Zeitlyn, B. (2006). Migration from Bangladesh to Italy and Spain. Rmmru: Dhaka.

Zeitlyn, B. (2016). Transnational Childhood: British Bangladeshis, Identities and Social Change. London: Palgrave Macmillan. 